筋肉内，消化管などが多く，関節内出血はまれ である. 先天性血友病の出血症状では関節内出 血が多く，同出血による関節障害が問題となる が，後天性血友病とは対照的である。皮下出血 や筋肉内出血はしばしば広範でなかなか消退せ ず，しばしば重度の貧血を伴う。さらに，後天 性血友病は筋肉注射，カテーテル挿入，気管切 開などの外科的処置後の出血遷延などが初発の 症状であることもある。特に，インヒビター力 価が低い軽症例では手術の際の術前検査で初め て診断される場合も多々ある。

\section{3. 診断}

後天性血友病の診断の第一歩は，特に中高 年以降に突然見られる出血症状と活性化部分 トロンボプラスチン時間（aPTT）の延長であ る。このような症例に遭遇した場合には，第 VIII 因子活性の測定を実施し，低下する場合は 抗第 VIII 因子インヒビターの測定を実施する. 後天性血友病ではプロトロンビン時間，血小 板数，トロンビン時間，フィブリノゲンや von Willebrand 因子（VWF）は正常である。

後天性血友病の凝血学的診断においていくつ かの注意点があるので列挙する。

\section{1）第 VIII 因子が存在する例が多い}

後天性血友病の本態である抗第 VIII 因子イ ンヒビターは後述するように第 VIII 因子と共 存する夕イプが多い。しかしながら，先天性血 友病と異なり，最も特徴的なことは第 VIII 因 子が存在しても出血症状は重篤であることであ る。この原因としてはインヒビター力価が低い 症例の場合とタイプ 2 インヒビターが考えられ る、インヒビター力価が低い場合は，Bethesda 法で検出されない場合もある。特に, 回復期, インヒビターが検出されなくとも第 VIII 因子 活性が低下している場合は，インヒビター消失 と判断するのは早計である. 抗第 VIII 因子イ ンヒビターは第 VIII 因子活性の抑制パターン によりタイプ 1 インヒビターとタイプ 2 インヒ ビターに分類される。前者はインヒビターの濃
度に比例直線的に第 VIII 因子を失活するもの で先天性血友病に出現するインヒビターの多く がこのタイプを呈する。一方，タイプ 2 インヒ ビターは比例直線的に失活しないタイプで，血 漿検体を希釈しても残存第 VIII 因子活性が低 值を示すためにベセスダ法によるインヒビター 測定がしばしば困難になる。したがって，夕イ プ 2 インヒビターの場合は，第 VIII 因子残存 活性が $50 \%$ を越え，かつ，50\%に最も近くな るときの希釈倍数を持ってインヒビター力価と する.

2）他の内因系凝固因子活性も低下する場合

高力価の抗第 VIII 因子インヒビターが存在 する場合，第 IX 因子や他の内因系凝固因子活 性も低下することがある。これは凝固因子活性 をそれぞれの凝固因子の欠乏血漿を基質として 測定する 1 段法で測定する場合，抗第 VIII 因 子インヒビターが基質中の第 VIII 因子を失活 するためであり，複合凝固因子インヒビターと 判断するのは早計である. 複合凝固因子インヒ ビターとの鑑別が困難な場合は，それぞれの凝 固因子活性のみならず凝固因子抗原を測定する 方法や ELISA などで特異的抗凝固因子結合抗 体を検出する方法がある.

ループスアンチコアグラント（LA）が陽性 でも aPTT は延長し，また，第 VIII 因子をはじ め内因系凝固因子活性も見かけ上 , 低下するた めに日常臨床上鑑別が困難なことがある。これ は LA が凝固因子測定で使用するリン脂質をブ ロックするためである。LA が陽性な場合，血 漿検体を十分希釈して測定すること，血小板や リン脂質中和試験を実施すること，第 VIII 因 子抗原を測定することなどで鑑別できる。

\section{4. 治 療}

後天性血友病の治療の根本は止血療法と免疫 学的療法である。しかしながら, 出血症状はイ ンヒビターが存在する限り出現する危険性があ るために, 免疫学的治療によるインヒビター除 去が後天性血友病の最も重要な治療である。 


\section{1）止血療法}

後天性血友病の出血症状はしばしば重篤で重 度の貧血を伴う。特に生命の危険を及ぼすよう な重篤な出血や進行中の出血症状については 可及的に止血療法を開始する必要がある。し かしながら, 出血症状が慢性期で貧血の進行も ない場合は積極的な止血療法は不要で, むしろ 後述するインヒビター除去のための免疫的治療

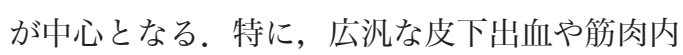
出血も止血後も症状は相当な期間持続する. し たがって, 出血症状の存在のみで止血療法を持 続するのは, 望ましくない. 止血療法の主体は バイパス止血製剤によるバイパス止血療法であ る。現在，わが国で使用できるバイパス止血製 剂は活性型第 VII 因子製剂（rFVIIa：ノボセブ ン；ノボノルディスク社）と活性型プロトロン ビン複合体製剤（aPCC：Feiba イムノ；Baxter 社）である。

\section{(1) rFVIIa}

\section{a. 止血機序}

出血に基づく血管損傷により露出した組織因 子（TF）で形成される FVIIa-TF 複合体が血液 凝固外因系を通じて第 X 因子を活性化して微 量なトロンビンが生成される。初期に生成され るトロンビンは止血に必要な安定したフィブリ ン形成には不十分であるが, 血小板や第 V 因子, 第 VIII 因子，第 XI 因子を活性化する結果活性 化された血小板上で大量のトロンビンが生成さ れる ${ }^{3)}$.さらに高濃度のトロンビンが thrombin activatable fibrinolysis inhibitor（TAFI）を抑制 して安定したフィブリンが形成される.

\section{b. 止血療法の実際}

従来, rFVIIa は先天性血友病に発生する抗第 VIII 因子同種抗体陽性例の止血療法製剤として 使用されたが, 後天性血友病の止血療法製剤と しても有用であることが報告されている。実際 の投与方法は血友病インヒビターの止血療法に 準ずる（インヒビター保有先天性血友病患者に 対する止血治療ガイドライン案. 日本血栓止血 学会学術標準化委員会血友病部会血友病ガイド
ライン作成小委員会. 血栓止血誌投稿準備中). 一般的に初回投与量は $90 \mu \mathrm{g} / \mathrm{kg}$ ，その後は出血 症状の重症度によるが $60 〜 120 \mu \mathrm{g} / \mathrm{kg}$ を 2-3 時 間毎に反復投与する。軽度〜中等度の出血であ れば 1〜3 回の投与を行い, 必要であればさら に 1 回の追加投与を行う。重篤な出血や手術時 は 2 時間毎の投与を $1 \sim 2$ 日間行い, 以後漸減 する. 多くは 1-2 週間の投与で止血が得られる が，特に重篤な場合は $2 \sim 3$ 週間必要な場合が あるが，漫然と使用するのは薦められない．臨 床的止血効果のみならず貧血の改善も参考に投 与計画を立てる。

\section{（2）aPCC 製剂}

\section{a. 止血機序}

aPCC には活性化凝固因子が含まれる。止血 機序については諸説があるが, 最近は $\mathrm{aPCC} の$ 止血機序の本態はプロトロンビンと活性型第 $\mathrm{X}$ 因子であり，第 $\mathrm{V}$ 因子の存在でさらにトロン ビン生成が増幅されることが家鬼のインヒビ ターモデルで明らかにされている4).

\section{b. aPCC 製剂使用の実際}

rFVIIa と同様血友病インヒビターの治療製 剂として使用されており，後天性血友病の止血 療法においてもこれに準ずる。基本的には 50 〜 100 単位/ $\mathrm{kg}$ を 8 12 時間毎に緩徐に静注も しくは点滴静注する。軽度〜中等度の出血で は $1 \sim 2$ 回/日の投与 $1 \sim 3$ 日間投与する. 重篤 な出血や手術の場合, $2 \sim 3$ 回/日の投与で継続 するが，Feibaの連続使用においてはわが国で は保険診療上の 3 日以内の制限があり，以後は rFVIIa に変更せざるを得ない. なお， 1 日の最 大投与量は 200 単位 $/ \mathrm{kg}$ を越えないように使用 する。

\section{（3）バイパス止血療法製剂の副作用}

rFVIIa や aPCC 製剂投与に関連する副作用は きわめてまれであるが, 血栓症が多い. $\mathrm{APCC}$ ではDIC, 心筋梗塞, 肺血栓塞栓症などが, rFVIIa では心筋梗塞, 脳血管障害, 深部静脈血. 栓，肺血栓塞栓症，DIC などの報告がある。た だし, 発症者の約 $80 \%$ に高齢，虚血性心疾患， 
肥満，高脂血症などの血栓症発症リスクファク ターを有する患者や製剤の大量・長期使用時に 発生している。したがって，おおむね安全では あるが，血栓マーカーの定期的チェックは必要 である。

\section{（4）第 VIII 因子製剂}

後天性血友病は夕イプ 2 インヒビターが多 く，第 VIII 因子製剤の投与量の決定がきわめ て困難である。したがって, 特に高力価インヒ ビター症例では無効なことが多い.

（5）酢酸デスモプレッシン（DDAVP）

DDAVP は FVIII/VWF 貯蔵プールから両因子 を分泌させる作用があり，FVIII/VWFを有す る中等〜軽症血友病 $\mathrm{A}$ およびタイプ IVWDの 止血治療製剤として従来から使用されている。 本製剤はバイパス止血療法製剤や第 VIII 因子 製剤より安価であり, 軽度の出血症状に対して 考慮すべき製剤である。ただし, 高力価インヒ ビター例や重度の出血症状には無効な例も多 い. DDAVP の使用前に, 投与後の第 VIII 因子 活性をモニタリングして凝血学的効果を評価し ておくことが必要である。また，連続に使用す ると止血効果は低下する。

\section{2) 免疫学的治療法}

後天性血友病の最も重要な治療法である。基 本的には免疫抑制剤が中心である。分娩や薬剤 関連性の後天性血友病では, インヒビターが自 然に消失する場合もある。したがって, 経過観 察できる場合もあるが，基本的には早期免疫抑 制剂の投与開始が勧められている。第一選択と して最も多く使用されている製剤はコルチコス テロイドである。投与量は一般的に $1 \mathrm{mg} / \mathrm{kg} /$ 日で投与期間は 3-6 週間である.

\section{II. 後天性 von Willebrand 病}

\section{1. 定義と疫学}

後天性 VWD は後天性に von Willebrand 因子 （VWF）が低下することにより出血傾向を呈す る疾患である。男女差はない，発症年齢の中央
值は 62 歳である。ほとんどの症例で何らかの 基礎疾患がみられ，リンパ増殖性疾患，骨髄増 殖性疾患，悪性腫瘍および自己免疫疾患，心血 管疾患などの頻度が高い．特に，単クローン性 蛋白を伴う疾患，骨髄腫，原発性マクログロブ リン血症などが知られている ${ }^{5)}$. 抗 VWF 抗体 の出現による免疫学的な原因と, 非免疫学的な 原因がある，非免疫的な機序で発症する後天性 VWD はVWF のクリアランスの増加が主要な 原因である，具体的にはVWF の蛋白分解の立 進，腫瘍細胞表面への非特異的吸着および結合 などが報告されている6).

\section{2. 症状}

VWD と同様に紫斑，鼻出血および口腔内出 血などの皮膚粘膜出血症状が主体である.

\section{3. 診断}

自己免疫疾患や悪性腫瘍などの基礎疾患を背 景に後天的に皮膚粘膜出血を主体とした出血症 状をみた場合に本疾患を疑う。しかしながら， 約 30\%の症例では出血症状がみられない ${ }^{5)}$. ま た，合併疾患が見られない場合でも本疾患が疑 われた場合は，基礎疾患が潜む可能性があり， 精査の実施が必要である。出血時間や aPTT は 正常な例もあり診断価的価值は低い。第 VIII 因子活性は約 $60 \%$ の症例で低下する。VWF 抗 原（VWF : Ag）の中央值は $33 \mathrm{IU} / \mathrm{dl}$ で低下す る例が多いが，正常な例もあり，リストセチン コファクター活性（VWF : Rcof）やコラーゲン 結合能（VWF : CBA）などの VWF 機能測定が より有用である。両測定值の中央值は $20 \mathrm{IU} / \mathrm{dl}$ である。第 VIII 因子インヒビターの測定と同 様に Bethesda 法に基づいて，正常血漿と患者 血漿を混合して残存した VWF 活性の低下によ り診断できるが，感度は低くインヒビター陽性 例は少ない. ELISAにより特異的抗 VWF 抗体 IgG を検出することも可能である。約 $2 / 3$ の 症例で高分子量 VWF マルチマーの欠落を認め $ろ^{5)}$. 


\section{4. 治 療}

一般に，DDAVP が第一選択の止血治療製剂 として薦められている。本剤の有効性は症例に より異なり，治療にあたつては試験投与による BT，FVIII : C および VWF 機能測定による評価 が必要である。DDAVP の無効例は FVIII/VWF 複合体製剤を用いる。投与後のモニタリングが 必須である。近年，欧米では rFVIIaの有効例 が報告されている 皮質ホルモン製剤，免疫抑制剂， $\gamma$ グロブリン 製剤などが主に使用される。

\section{文献}

1）嶋 緑倫, 田中一郎, 川合陽子, 辻 肇, 中村 伸, 森田隆 司 : 本邦における血液凝固後天性インヒビターの実態.
血栓止血誌 $14:$ 107-121, 2003.

2) 田中一郎, 天野景裕, 瀧 正志, 岡 敏明, 酒井道生, 白 幡 聡, 高田昇, 高松純樹, 竹谷英之, 花房秀次, 日 笠 聡, 福武勝幸, 藤井輝久, 松下 正, 三間屋純一, 吉 岡 章, 嶋 緑倫. わが国における後天性凝固因子インヒ ビターの実態に関する 3 年間の継続調査一予後因子に関 する検討一血栓止血誌, 印刷中

3) Hoffman M, Monroe DM : A cell-based model of hemostasis. Thromb Haemost 85 : 958-965, 2001.

4) Turecek PL, Varadi K, Gritsch H, Scwarz HP : FEIBA : mode of action. Haemophilia 10 (Suppl 2) : 3-9, 2004

5) Acquired von Willebrand Syndrome : Data from an International Registry On behalf of the Subcommittee on von Willebrand factor. Federici AB, Rand JH, Bucciarelli P, Budde U, van Genderen PJJ, Mohri H, Meyer D, Rodeghiero F, Sadler JE Thromb Haemost $84:$ 345-349, 2000.

6) 毛利 博: 後天性フォン・ウイルブランド症候群. 血栓止 血誌 $14: 82-90,2003$.

7) Successful treatment with recombinant factor VIIa of therapy-resistant severe bleeding in a patient with acquired von Willebrand disease. Friederich PW, Wever PC, Briet E, Doorenbos CJ, Levi M. Am J Hematol 66 : 292-294, 2001. 